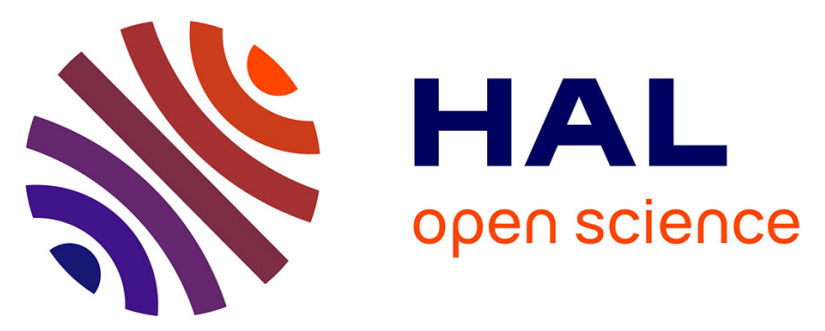

\title{
Exposure to metal oxide nanoparticles administered at occupationally relevant doses induces pulmonary effects in mice
}

Mirlande Présumé, Angélique Simon-Deckers, Céline Tomkiewicz-Raulet, Béatrice Le Grand, Jean Tran van Nhieu, Gregory Beaune, Olivier Duruphty, Jean Doucet, Xavier Coumoul, Jean-Claude Pairon, et al.

\section{To cite this version:}

Mirlande Présumé, Angélique Simon-Deckers, Céline Tomkiewicz-Raulet, Béatrice Le Grand, Jean Tran van Nhieu, et al.. Exposure to metal oxide nanoparticles administered at occupationally relevant doses induces pulmonary effects in mice. Nanotoxicology, 2016, 10 (10), pp.1535-1544. 10.1080/17435390.2016.1242797 . hal-01496265

\section{HAL Id: hal-01496265 \\ https://hal.sorbonne-universite.fr/hal-01496265}

Submitted on 27 Jul 2019

HAL is a multi-disciplinary open access archive for the deposit and dissemination of scientific research documents, whether they are published or not. The documents may come from teaching and research institutions in France or abroad, or from public or private research centers.
L'archive ouverte pluridisciplinaire HAL, est destinée au dépôt et à la diffusion de documents scientifiques de niveau recherche, publiés ou non, émanant des établissements d'enseignement et de recherche français ou étrangers, des laboratoires publics ou privés. 


\title{
Nanotoxicology \\ Nanotoxicology
}

\section{Exposure to metal oxide nanoparticles administrated at occupationally-relevant doses induces pulmonary effects in mice}

\author{
Mirlande Présumé, Angélique Simon-Deckers, Céline Tomkiewicz-Raulet, \\ Béatrice Le Grand, Jeanne Tran Van Nhieu, Gregory Beaune, Olivier \\ Duruphty, Jean Doucet, Xavier Coumoul, Jean-Claude Pairon, Jorge \\ Boczkowski, Sophie Lanone \& Pascal Andujar
}

To cite this article: Mirlande Présumé, Angélique Simon-Deckers, Céline Tomkiewicz-Raulet, Béatrice Le Grand, Jeanne Tran Van Nhieu, Gregory Beaune, Olivier Duruphty, Jean Doucet, Xavier Coumoul, Jean-Claude Pairon, Jorge Boczkowski, Sophie Lanone \& Pascal Andujar (2016): Exposure to metal oxide nanoparticles administrated at occupationally-relevant doses induces pulmonary effects in mice, Nanotoxicology, DOI: $10.1080 / 17435390.2016 .1242797$

To link to this article: http://dx.doi.org/10.1080/17435390.2016.1242797

Accepted author version posted online: 28 Sep 2016.

Submit your article to this journal $\sqsubset$

W Article views: 17

View related articles

View Crossmark data $₫$ 
Exposure to metal oxide nanoparticles administrated at occupationally-relevant doses induces pulmonary effects in mice

Mirlande Présumé ${ }^{1, *}$, Angélique Simon-Deckers ${ }^{1,2, *}$, Céline Tomkiewicz-Raulet ${ }^{3,4}$, Béatrice Le Grand ${ }^{3}$, Jeanne Tran Van Nhieu ${ }^{5,6}$, Gregory Beaune ${ }^{7}$, Olivier Duruphty ${ }^{7}$, Jean Doucet ${ }^{2}$, Xavier Coumoul $^{3,4}$, Jean-Claude Pairon ${ }^{1,6,8}$, Jorge Boczkowski ${ }^{1,6,9}$, Sophie Lanone ${ }^{1,8, \$}$, Pascal Andujar ${ }^{1,6,8, \$, \#}$.

${ }^{1}$ INSERM, U955, Equipe 4, Créteil, F-94000, France.

${ }^{2}$ CNRS, UMR 8502, Laboratoire de Physique des Solides, Orsay, F-91400, France

${ }^{3}$ INSERM, UMR-S 1124, Toxicologie Pharmacologie et Signalisation cellulaire, Paris, F75006, France.

${ }^{4}$ Université Paris Descartes, Paris, F-75006, France

${ }^{5} \mathrm{CHU}$ Henri Mondor, Service d'Anatomo-pathologie, Créteil, F-94000, France.

${ }^{6}$ Université Paris Est-Créteil, Faculté de Médecine, Créteil, F-94000, France.

${ }^{7}$ Sorbonne Universités, UPMC Université Paris 06, CNRS, Collège de France, Laboratoire de Chimie de la Matière Condensée de Paris, Paris, F-75005, France

${ }^{8}$ Centre Hospitalier Intercommunal de Créteil, Service de Pneumologie et de Pathologie Professionnelle, Créteil, F-94000, France.

${ }^{9}$ DHU A-TVB, Service d'explorations fonctionnelles respiratoires, Assistance Publique Hôpitaux de Paris, Hôpitaux Universitaires Henri Mondor, Créteil, F-94000, France.

* or \$: equal contribution

\#: Corresponding author: Pascal Andujar

Phone and Fax: +33 157022090

Address: Faculté de Médecine de Créteil, 8 rue du Général Sarrail, Créteil, F-94000, France

Email: pascal.andujar@inserm.fr

Running title: Pulmonary effects in mice of metal oxide nanoparticles administrated at occupationally-relevant doses. 


\section{ABSTRACT}

In spite of the great promises that the development of nanotechnologies can offer, concerns regarding potential adverse health effects of occupational exposure to nanoparticle (NP) is raised. We recently identified metal oxide NP in lung tissue sections of welders, located inside macrophages infiltrated in fibrous regions. This suggests a role for these NP in the lung alterations observed in welders.

We therefore designed a study aimed to investigate the pulmonary effects, in mice, of repeated exposure to NP administrated at occupationally-relevant doses. We therefore chose 4 metal oxide NP representative of those found in the welder's lungs: $\mathrm{Fe}_{2} \mathrm{O}_{3}, \mathrm{Fe}_{3} \mathrm{O}_{4}, \mathrm{MnFe}_{2} \mathrm{O}_{4}$ and $\mathrm{CrOOH}$. These NP were administrated weekly, for up to 3 months, at 2 different doses: 5 $\mu \mathrm{g}$, chosen as occupationally-relevant to welding activity, and $50 \mu \mathrm{g}$, chosen as occupationally-relevant to the context of a NP-manufacturing facility. Our results show that 3 month-repeated exposures to $5 \mu \mathrm{g}$ NP induced limited pulmonary effects, characterized by the development of a mild peribronchiolar fibrosis observed for $\mathrm{MnFe}_{2} \mathrm{O}_{4}$ and $\mathrm{CrOOH} \mathrm{NP}$ only. This fibrotic event was further extended in terms of intensity and localization after the repeated administration of $50 \mu \mathrm{g} \mathrm{NP}$ : all but $\mathrm{Fe}_{2} \mathrm{O}_{3} \mathrm{NP}$ induced the development of peribronchiolar, perivascular, and alveolar fibrosis, together with an interstitial inflammation. Our data demonstrate for the first time a potential risk for respiratory health posed by repeated exposure to NP at occupationally-relevant doses. Given these results, the development of occupational exposure limits specifically dedicated to NP exposure might therefore be an important issue to address.

Keywords: nanoparticles - occupationally-relevant dose - pulmonary effect - occupational exposure limit - welding fume. 


\section{INTRODUCTION}

Atmospheric pollution has long been known to potentially induce adverse health effects in the general population [1]. Particulate pollution represents one component of the atmospheric pollution that is associated with an increased morbidity and mortality, in particular at the cardiovascular and respiratory levels [2-5]. Nanoparticles (NP) constitute an important and still growing part of particulate pollution not only in the environmental context, but also in occupational settings.

At workplace, NP pollution can be emitted secondary to various industrial processes, such as arc-welding. During this process, welding fumes contain NP that represent up to $10 \%$ in mass and $80 \%$ in number of the total particles emitted [6-9]. NP can also be emitted intentionally at workplace, thereby generating manufactured NP. Exposure of workers to NP can occur during the initial production of NP, as well as during their further processing, dispersion and/or integration in secondary products. NP concentrations up to several $\mathrm{mg} / \mathrm{m}^{3}$ have been detected in workplaces manufacturing nanosized iron oxides, titanium dioxide, silver or nanostructured materials used for the electric industry for example [10-14].

A growing number of workers is estimated to be involved in work processes linked to the intentional or unintentional production of NP; up to 6 millions of workers will potentially be exposed to NP in 2020 [15]. In spite of the great promises that the development of nanotechnologies can offer, concerns regarding potential adverse health effects of such occupational exposure to NP is raised. However, very few data are currently available, probably because of the relatively recent development of nanotechnologies and production of manufactured NP. On the other hand, NP unintentionally emitted during an occupational activity such as welding is however not new, and we can, as such, take advantage of the literature available on this population of workers. Various adverse respiratory outcomes have been described in welders, among which inflammation and lung remodeling are largely 
reported $[16,17]$. We recently identified metal oxide NP (Fe, Mn, Cr oxides essentially) in lung tissue sections of welders [18]. These metal oxide NP were located inside macrophages present in the alveolar lumen and infiltrated in fibrous regions, which suggests a role for these NP in the lung alterations observed in welders.

To deepen our findings and extend them to occupational settings where NP are intentionally emitted, we designed an in vivo study aimed to investigate the pulmonary effects, in mice, of repeated exposure to NP administrated at occupationally-relevant doses. Our underlying hypothesis was that repeated exposure to NP at occupational levels could lead to lung remodeling similar to that observe in lung tissue from welders. Therefore, 4 metal oxide NP in relationship with the occupational exposure of welding, and that we previously identified in lung tissue sections from welders [18] were selected: $\mathrm{Fe}_{2} \mathrm{O}_{3}, \mathrm{Fe}_{3} \mathrm{O}_{4}, \mathrm{MnFe}_{2} \mathrm{O}_{4}$ and $\mathrm{CrOOH}$. These NP were weekly administrated to mice up to 3 consecutive months, at 2 doses each one being relevant to occupational settings: $5 \mu \mathrm{g}$, chosen as occupationally-relevant to the welding activity, and $50 \mu \mathrm{g}$, chosen as occupationally-relevant to the context of a NP-manufacturing facility. Our results demonstrate that, while repeated exposures to $5 \mu \mathrm{g}$ NP induced only limited pulmonary, administration of $50 \mu \mathrm{g}$ NP induced the development of peribronchiolar, perivascular, and alveolar fibrosis, together with an interstitial inflammation in response to all but $\mathrm{Fe}_{2} \mathrm{O}_{3}$ NP. Overall, these data provide new evidence for a potential risk for health of repeated exposure to NP at occupationally-relevant doses. 


\section{METHODS}

\section{Metal oxide NP}

Four NP representative of welding occupational exposure $\left(\mathrm{Fe}_{2} \mathrm{O}_{3}, \mathrm{Fe}_{3} \mathrm{O}_{4}, \mathrm{MnFe}_{2} \mathrm{O}_{4}, \mathrm{CrOOH}\right)$ were chemically synthetized and characterized as powder and as suspension after sonication as previously described [18]. Stock solutions of NP suspensions (2 $\mathrm{mg} / \mathrm{mL})$ were prepared in ultrapure water and stored at $-80^{\circ} \mathrm{C}$. Just before use, the suspensions were sonicated for 10 min in ultrasonic bath (Elmasonic S30H). NP suspensions were observed using a JEOL1400TEM at $120 \mathrm{kV}$. The observation of at least $200 \mathrm{NP}$ per suspension showed that all NP are spherical and present an average diameter of 20-25 nm $\left(\mathrm{Fe}_{2} \mathrm{O}_{3}, \mathrm{Fe}_{3} \mathrm{O}_{4}\right.$ and $\left.\mathrm{MnFe}_{2} \mathrm{O}_{4}\right)$ or $15 \mathrm{~nm}$ $(\mathrm{CrOOH})$ (Supplemental Figure S1). Dynamic light scattering experiments demonstrate that all NP formed aggregates in solution, their size largely depending on the chemical nature of the NP considered (Supplemental Figure S2).

\section{Animal housing and handling}

\section{Animal housing}

Male C57BL/6 mice 6-7 weeks of age were purchased from Janvier (Le Genest-St-Isle, France) and acclimated during 1 week. All mice were supplied with food (SAFE, Auguy, France) and tap sterilized water ad libitum in standard wire-topped cages in a controlled environment, with a $12 \mathrm{~h}$ light/dark cycle. All experiments were approved by our local Institutional Animal Care and Use Committee (Comité d'éthique - ComEth, ANSES/ENVA/UPEC, \#C2EA-16).

\section{Animal exposure to NP}

To estimate the amount of NP to administrate in our study in order to be relevant for realistic occupational exposure, we utilized the following equation [17]: 
Daily deposited dose of NP = occupational exposure limit (OEL) x NP mass fraction in occupational emission $\mathrm{x}$ minute ventilation $\mathrm{x}$ duration $\mathrm{x}$ NP deposition efficiency

with $1 /$ OEL for welding fumes at $5 \mathrm{mg} / \mathrm{m}^{3}, 2 /$ a mass concentration of NP in welding fumes at $10 \%$ of the total particle emitted $3 /$ a mean minute ventilation at $22.500 \mathrm{~mL} / \mathrm{min}$ (tidal volume of $1500 \mathrm{~mL}$ and respiratory frequency of $15 / \mathrm{min}$ for a worker with moderate activity), 4/ a daily occupational exposure of 8 hours, and 5/ a mean deposition efficiency of NP in the alveolar region of $50 \%$ for an average NP aerodynamic diameter of $20 \mathrm{~nm} \mathrm{[18-21].}$ Importantly, these calculations do not account for particle clearance, but provide an estimate of the plausible worker exposure concentrations. Overall, the daily NP lung burden was estimated at $2.7 \mathrm{mg}$ per worker per day. Given the average worker weight $(70 \mathrm{~kg})$ and the average weight of the mice ( $25 \mathrm{~g})$, the daily deposited dose of NP for a mouse was estimated at $1 \mu \mathrm{g}$. Therefore, the dose of $5 \mu \mathrm{g}$ weekly was considered as representative of occupational exposure of workers in the context of an unintentional process such as welding $[8,9]$. The dose of $50 \mu \mathrm{g}$ weekly was subsequently calculated for a NP only-containing aerosol, within the $5 \mathrm{mg} / \mathrm{m}^{3}$ OEL.

Once a week, mice received Saline (Control group), 5 or $50 \mu \mathrm{g} \mathrm{NP}\left(\mathrm{Fe}_{2} \mathrm{O}_{3}, \mathrm{Fe}_{3} \mathrm{O}_{4}, \mathrm{MnFe}_{2} \mathrm{O}_{4}\right.$, $\mathrm{CrOOH}$ groups) administrated by pharyngeal aspiration performed under anesthesia $(1.6 \mathrm{mg}$ ketamine (Virbac, Carros, France) plus $300 \mathrm{mg}$ xylazine (Bayer®, Puteaux, France)). Mice were sacrificed as previously described $24 \mathrm{~h}, 1$ week, 1 or 3 months after the first exposure [22]. A schematic representation of the experimental protocol is given in Supplemental Figure S3.

\section{Lung tissue collection}

At the time of the sacrifice, mice were anesthetized and their right lung was inflated, fixed with $10 \%$ of OCT (Optimal Cutting Temperature) at a constant pressure of $20 \mathrm{~cm} \mathrm{H}_{2} \mathrm{O}$ and paraffin-embedded for further histological and immunohistochemical analysis. Before being 
frozen in liquid nitrogen and stored at $-80^{\circ} \mathrm{C}$, left lung was lavaged with twice with $1 \mathrm{~mL}$ of physiological saline, removed from the chest cavity, and immediately frozen at $-80{ }^{\circ} \mathrm{C}$ for use in further experiments.

\section{Histological and immunohistochemical analysis}

Paraffin-embedded lung tissue sections $(5 \mu \mathrm{m})$ were stained with hematoxylin-eosin-saffron (HES) for histological examination or with Sirius Red for collagen deposition. The occurrence, localization and severity of histological lesions were assessed using a semiquantitative score adapted from Ashcroft [23]. At least 10 fields per lung tissue section were analyzed (magnification x200), and a scale of 4 semi-quantitative fibrosis scores was utilized: [0: normal; 1: minimal fibrous thickening; 2 : moderate thickening of walls without obvious damage to lung architecture; 3: increased fibrosis thickening of walls with definite damage to lung structure and formation of fibrous bands or small fibrous masses] for peribronchial, perivascular or alveolar wall thickness extension.

A similar scale of 4 semi-quantitative scores was used for inflammatory infiltrates in the alveolar, bronchiolar or vessel lumen, peribronchiolar or perivascular walls, as well as in the interstitium [0: $<20$ inflammatory cells/field; $1: 21$ to $50 ; 2: 51$ to $100 ; 3:>100]$. Finally, the number of NP agglomerate/aggregate per field was also quantified (magnification x200).

Additionally, immunohistochemical ( $\mathrm{IHCh}$ ) analysis was performed using specific antibodies directed against Heme oxygenase (HO-1) protein as previously described [18].

\section{BALF analysis}

\section{Cellularity}


Free alveolar cells were recovered from the lavage fluid by centrifugation at $400 \mathrm{~g}$ for 15 min at $4{ }^{\circ} \mathrm{C}$. The cellular pellet was suspended in $150 \mu \mathrm{L}$ of physiological saline. An aliquot of the cell suspension was then examined using a hemocytometer to evaluate the total white cell number. For differential counts, the cell suspension was cytospun (cytospin-2, Shandon Products Ltd.), fixed in methanol, and stained with Diff Quick solution (Medion Diagnostics, Plaisir, France).

Alveolar epithelial barrier integrity and cytotoxicity evaluations

Total protein content and LDH concentrations in BALF were determined by the Bio-Rad protein assay (Bio-Rad, Marne-La-Coquette, France) and by the Cytotoxicity Detection Kit (Roche $\left.{ }^{\circledR}\right)$, respectively.

\section{Lung inflammation}

In order to evaluate lung inflammation, BALF content in Transforming growth factor beta (TGFß), Tumor Necrosis Factor alpha (TNFa) and Interleukin 1beta (IL1 $\beta$ ) proteins was quantified by DuoSet ${ }^{\circledR}$ ELISA as per the manufacturer's instructions (R\&D Systems, Lille, France).

\section{Quantification of mRNA expression in lung homogenates}

mRNA were isolated from frozen lung tissue samples using the RNeasy Mini Kit (Qiagen, Courtaboeuf, France). mRNA expression of genes related to inflammatory (TNFa, Monocyte Chemoattractant Protein 1 - MCP-1, Interleukin 6 - IL-6, Prostaglandin-endoperoxidase synthase 2 - PTGS, Regulated upon activation normal T-cell express, and presumably secreted - RANTES) and oxidative responses (NAD(P)H/quinone oxidoreductase - NQO-1, Cytochrome P450-family 1 subfamily A-polypeptide 1 - CYP1A1) was measured by relative quantification method using GAPDH (glyceraldehyde-3-phosphate dehydrogenase) as the 
housekeeping gene and performed with a PCR ABI 7700 apparatus (Applied Biosystems, Courtaboeuf, France) with SybrGreen technologies (Applied Biosystems). Primer sets are shown in Table 1S.

\section{Statistical analysis}

Eight animals per experimental group were used for each time-point and each dose, except for one week exposure at $50 \mu \mathrm{g}$ where 10 mice per experimental group were used. Taking into account the possibility of non-normal distribution in the hypothetic mice population, and the number of mice (lower than 30 independent mice), non-parametric tests (Kruskal-Wallis statistical test followed by Dunn's multiple comparison test) were used (GraphPad Prism software, version 5.01, USA). For all statistical tests, p values smaller than 0.05 were considered as significant. Values are expressed as the mean or median and interquartile range for histological semi-quantitative scores. 


\section{RESULTS}

\section{Histological analysis of lung tissue sections}

Figure 1 shows representative HES (Panel A) and Sirius Red (Panel B) images of lung tissue sections obtained after weekly exposure of mice to $5 \mu \mathrm{g}$ NP during 3 months. Semiquantification of the histological alterations showed a small but significant increase in peribronchiolar thickness in response to $\mathrm{MnFe}_{2} \mathrm{O}_{4}$ or $\mathrm{CrOOH} \mathrm{NP}$, but not in response to $\mathrm{Fe}_{2} \mathrm{O}_{3}$ or $\mathrm{Fe}_{3} \mathrm{O}_{4} \mathrm{NP}$ (Figure 1, Panel C). These modifications were not present at shorter exposure durations (data not shown).

At the dose of $50 \mu \mathrm{g}$ administrated weekly during 3 months, all NP induced a pronounced lung fibrotic remodeling characterized by the thickening of alveolar, peribronchiolar as well as perivascular walls, together with the presence of interstitial lung inflammation (Figure 2). These modifications were not present at shorter exposure durations (data not shown). Whatever the experimental condition, neither granuloma formation nor the development of emphysema could be observed. Moreover, no bronchiolar hyperplasia could be detected.

The presence of microscopically observable NP aggregates/agglomerates was not detected in $5 \mu \mathrm{g}$-exposed animals, but was detectable in all animals exposed to $50 \mu \mathrm{g}$ weekly, essentially in alveolar and bronchiolar lumens, with a significantly higher number of aggregates/agglomerates present in animals weekly exposed to $50 \mu \mathrm{g} \mathrm{MnFe}_{2} \mathrm{O}_{4}$ or $\mathrm{CrOOH} \mathrm{NP}$ as compared to those exposed to $\mathrm{Fe}_{2} \mathrm{O}_{3}$ or $\mathrm{Fe}_{3} \mathrm{O}_{4} \mathrm{NP}$ (Figure 3).

\section{Alveolar epithelial barrier integrity}

We next addressed the integrity of the epithelial barrier by assessing the total protein content and LDH release in the BALF of NP-exposed mice. As shown in Figures 4 and 5, there was a significant increase of BALF total protein content only in the $\mathrm{MnFe}_{2} \mathrm{O}_{4}$-exposed mice after 1 
month of weekly exposure to $5 \mu \mathrm{g}$ NP (Figure 4, Panel A). No significant modification of BALF total protein content was observed for the other experimental conditions. Moreover, no significant modification of LDH release was observed, whatever the exposure duration, the dose or the chemical nature of the NP administered (Figures 4, 5, Supplemental Figure S4).

\section{Pulmonary inflammatory and oxidative responses}

As the presence of NP in the lungs has been related to the induction of inflammatory and oxidative responses $[24,25]$, we next explored the total cellularity of BALF. As shown in Figures 4, 5, and Supplemental Figure S4, BALF total cellularity was significantly increased only in $\mathrm{CrOOH}$-exposed mice as compared to unexposed animals, whatever the dose received (5 or $50 \mu \mathrm{g}$ weekly), after a 3 months-exposure. The cell differential was kept unchanged, whatever the experimental condition; only macrophages and rare neutrophils were detected in BALF samples (data not shown).

We next evaluated the release in the BALF of NP-exposed mice, of 3 inflammatory cytokines known to represent important markers of the pulmonary response to NP exposure: TNFa, TGFß and IL1ß [24-26]. For the dose of NP relevant to welding activity (5 $\mu \mathrm{g})$, only CrOOHexposed animals present a transient but significant increase in TNFa secretion 24 hours after the first exposure as compared to unexposed mice (Supplemental Figure S4, Panel C). For the highest dose of NP (50 $\mu \mathrm{g}$ weekly), all but $\mathrm{Fe}_{2} \mathrm{O}_{3} \mathrm{NP}$ induced significant increases in BALF TNFa content after 1 day (Supplemental Figure S4, Panel D). This upregulated secretion could still be observed after 1 month (for $\mathrm{Fe}_{3} \mathrm{O}_{4}$ - and $\mathrm{CrOOH}$-exposed animals) or 3 months (for $\mathrm{MnFe}_{2} \mathrm{O}_{4}$ - and $\mathrm{CrOOH}-$ exposed mice, Figures 4 and 5) repeated exposure. Interestingly, TGFß secretion was significantly increased in $\mathrm{MnFe}_{2} \mathrm{O}_{4}$-exposed mice, after 3 month repeated 
exposure to $50 \mu \mathrm{g}$ NP (Figure 5). IL1ß BALF content was not modified by NP exposure, whatever the chemical nature of the NP, the dose or the exposure duration studied.

We further evaluated inflammation at the level of the whole lung, by qPCR analysis. As shown in Figures 6, 7 and Supplemental Figure S5, a transient increase in MCP-1 mRNA expression was observable after 1 day of exposure to $5 \mu$ g Fe-based $\mathrm{NP}\left(\mathrm{Fe}_{2} \mathrm{O}_{3}, \mathrm{Fe}_{3} \mathrm{O}_{4}\right.$ and $\mathrm{MnFe}_{2} \mathrm{O}_{4}$ ). This increase was also observed after 1 day and 1 month weekly repeated exposure to $\mathrm{CrOOH}$ NP. Moreover, TNFa mRNA expression was increased in response to all NP after 3-months weekly repeated exposure to the occupationally-relevant dose of $5 \mu \mathrm{g}$ (Figure 7). This increase in TNFa mRNA expression was also detectable in the $50 \mu \mathrm{g}$ exposed groups, either transiently $\left(\mathrm{Fe}_{2} \mathrm{O}_{3}\right.$ and $\left.\mathrm{MnFe}_{2} \mathrm{O}_{4}\right)$ or steadily $\left(\mathrm{Fe}_{3} \mathrm{O}_{4}\right.$, starting after 1 month, and $\mathrm{CrOOH}$, at all exposure durations). Moreover, in $\mathrm{Fe}_{3} \mathrm{O}_{4-}$ and $\mathrm{CrOOH}$-exposed mice, MCP-1 and PTGS mRNA expressions were increased as compared to that measured in unexposed mice after 1 and 3 months. The same was true for IL-6 mRNA expression after 1 month (Figure 6, Panel B).

As for the oxidative response, no major modification of NQO1 or CYP1A1 expression could be detected in the $5 \mu$ g-exposed animals, except for a significant increase in CYP1A1 expression after 1 day of exposure to $\mathrm{Fe}_{3} \mathrm{O}_{4} \mathrm{NP}$ (Supplemental Figure S5). However, in 50 $\mu$ g-exposed animals, the antioxidant NQO1 mRNA expression was significantly increased in $\mathrm{Fe}_{3} \mathrm{O}_{4^{-}}, \mathrm{MnFe}_{2} \mathrm{O}_{4^{-}}$and $\mathrm{CrOOH}-$ exposed mice after 1 month repeated exposure as compared to unexposed animals, and was still significantly increased after 3 months exposure duration in CrOOH-exposed mice (Figures 6 and 7). Neither modification of CYP1A1 mRNA expression nor that of HO-1 protein was detected, whatever the experimental condition (Figures 6, 7, 8 and Supplemental Figure S5). 


\section{DISCUSSION}

The general aim of our study was to investigate the pulmonary effects, in mice, of repeated exposure to NP administrated at occupationally-relevant doses. To achieve this aim, we developed an experimental protocol designed to mimic at best an occupational exposure in 2 working contexts: welding (unintentional NP production) and NP-manufacturing facility (intentional NP production).

Our results demonstrate that repeated exposure of mice to metal oxide NP at doses relevant to welding activity induce no (after $\mathrm{Fe}_{2} \mathrm{O}_{3}$ and $\mathrm{Fe}_{3} \mathrm{O}_{4}$ NP exposure) or only limited (after $\mathrm{MnFe}_{2} \mathrm{O}_{4}$ and $\mathrm{CrOOH}$ NP exposure) lung remodeling; in these latter animals, only a slight although significant peribronchiolar fibrosis could be observed after 3 months, without any major sign of inflammation. To the best of our knowledge, these results are the first to address the specific issue of the pulmonary effects of repeated exposures to metal oxide NP administrated at doses relevant to the occupational activity of welding. Indeed, although the relevance of the exposure dose is a long-time ongoing issue in the literature dedicated to NP exposure [27], the majority of the studies published so far have been conducted using doses that are largely over the calculated doses relevant to the welding activity: at least $1 \mathrm{mg} / \mathrm{kg}$ (corresponding to $25 \mu \mathrm{g}$ per animal for a $25 \mu \mathrm{g}$ mouse), and up to $500 \mu \mathrm{g}$ per animal. Moreover, these doses were most often administrated as a single bolus, which dampens the overall relevance of the results obtained in these studies $[28,29]$. Our results are therefore difficult to compare with data from the literature. However, considering the results obtained with the lowest doses used in previously published studies, the effects of weekly pulmonary exposures to Fe or Cr oxide NP can be described as limited; absence of acute inflammatory cell recruitment in the BALF in most cases, low levels of inflammatory cytokines secretion, and no histological modification after 1 month (longest time point analyzed in these studies) [26, 30-32, 33 6264]. Our results are in accordance with these data, and further extend them, 
not only to doses relevant to the occupational activity of welding, but also to longer exposure durations (up to 3 months) and to a more realistic scenario of repeated exposures instead of administration of NP as a single bolus. Interestingly, lung TNFa mRNA expression was increased in response to all NP after 3 months weekly exposure to $5 \mu \mathrm{g}$. Given the implication of this cytokine in the early events of inflammation, one could infer that longer exposure duration to doses of NP relevant to welding activity could lead to more pronounced lung alterations. We are fully aware that welding fumes cannot be summarized to only metal oxide $\mathrm{NP}$, as a complex mixture of particles (micrometric and nanometric) together with a number of potentially toxic gases (e.g. ozone, nitrogen oxide, nitrogen dioxide) are generated during the welding process [34]. However, the relevance of our findings is supported by the fact that we were recently able to link the presence of NP aggregates/agglomerates in lung tissues samples of arc-welders to the presence of similar fibrotic lesions [18]. Various adverse outcomes have been described in welders, and are not limited to pulmonary endpoints [34]. Therefore, although we found only limited pulmonary effects of repeated exposure to occupationally-relevant doses of metal oxide NP, extra-pulmonary adverse effects could have been detected. This could be particularly true for the brain for example, as exposure to $\mathrm{Mn}$ is associated with neurotoxicity in welders [34]. Moreover, an increase in the incidence of lung cancer has been described particularly in those exposed to $\mathrm{Cr}$ [34]. However, as the maximum exposure duration was 3 months in our study, this was probably not enough to evaluate the carcinogenicity of the exposure, even for a mouse presenting a 2.5 years life expectancy. As Mn- and Cr-based NP were the most potent to induce lung remodeling when utilized at doses relevant to welding, their extra-pulmonary effects could have been particularly interesting to evaluate. These outcomes should deserve further studies.

The mild pulmonary alterations detected at doses relevant to the occupational activity of welding were further extended both in terms of intensity and spatial distribution after repeated 
exposure of mice to doses relevant to the context of a NP-manufacturing facility; not only a more pronounced thickening of the peribronchial wall could be observed, but also that of perivascular and alveolar walls, together with the presence of an interstitial inflammation. These findings were observed in response to all but $\mathrm{Fe}_{2} \mathrm{O}_{3} \mathrm{NP}$, given at the same mass concentration. In an attempt to decipher the underlying molecular mechanisms of these fibrotic lesions, the expression pattern of MCP-1 mRNA in lung homogenates could be of interest, as MCP-1 expression was increased after 1 and/or 3 months of repeated exposure to $50 \mu \mathrm{g}$ of all but $\mathrm{Fe}_{2} \mathrm{O}_{3}$ NP. Indeed, MCP-1 is a chemokine synthetized by a large variety of cells including macrophages and fibroblasts, and which exerts chemotactic and activating effects on macrophages [35]. Moreover, it has been recently described that pulmonary fibroblast-derived MCP-1 drives fibroblast proliferation and migration in response to silicon dioxide [35]. It is also important to note that the secretion of TGF 3 was increased only in the BALF obtained from $\mathrm{MnFe}_{2} \mathrm{O}_{4}$-exposed animals during 3 months. Although we did not evaluate longer exposure durations, and given the essential role of this cytokine in the development of lung fibrosis, this result suggests that $\mathrm{MnFe}_{2} \mathrm{O}_{4}$-exposed animals could be particularly prone to lung remodeling, thanks to the implication of molecular mechanisms specific to this speciation of NP. This is also suggested by the fact that $\mathrm{MnFe}_{2} \mathrm{O}_{4}$-exposed animals develop peribronchiolar wall thickening after 3 months weekly exposure at doses relevant for welding activity. However, such remodeling was also present in animals repeatedly exposed to $5 \mu \mathrm{g} \mathrm{CrOOH} \mathrm{NP}$, which indicates the occurrence of other, yet unidentified, molecular mechanism(s) that could be responsible for lung remodeling in response to these NP.

Our data showed that $\mathrm{Fe}_{2} \mathrm{O}_{3} \mathrm{NP}$ were overall less reactive than $\mathrm{Fe}_{3} \mathrm{O}_{4} \mathrm{NP}$. This difference could be due to different degrees of solubility between NP. However, previous data from our lab using the same metal NP as those used in the present study indicate a very small if no 
solubility at all whatever the NP tested [18]. Another explanation for this difference could be the different accumulation profiles between $\mathrm{Fe}_{2} \mathrm{O}_{3}$ and $\mathrm{Fe}_{3} \mathrm{O}_{4} \mathrm{NP}$. However, the number and localization of NP aggregates/agglomerates were similar for these NP, thus underlying the importance of chemical speciation in NP's effects. Interestingly, previous data from our team demonstrated that $\mathrm{Fe}_{2} \mathrm{O}_{3} \mathrm{NP}$ were more reactive than $\mathrm{Fe}_{3} \mathrm{O}_{4} \mathrm{NP}$ in terms of pro-inflammatory cytokines secretion by macrophages [18]. This suggests that macrophages might not be the essential or only target cell type to drive lung remodeling in response to iron oxide NP. Interestingly, although aggregates/agglomerates of metal oxide NP could be detected in all groups of animals in the present study (at the $50 \mu \mathrm{g}$ dose), yet all but $\mathrm{Fe}_{2} \mathrm{O}_{3} \mathrm{NP}$ were able to induce fibrotic lesions. However, the number of aggregates/agglomerates observed 3 months after repeated exposure to $\mathrm{Fe}_{3} \mathrm{O}_{4} \mathrm{NP}$, which was lower than after exposure to $\mathrm{MnFe}_{2} \mathrm{O}_{4}$ or $\mathrm{CrOOH} \mathrm{NP}$, didn't affect the intensity of the remodeling, which was similar for the $3 \mathrm{NP}$. It must be noted that, as our study was dedicated to investigate the pulmonary effects of repeated exposure to NP administrated at occupationally-relevant doses, the critical endpoint we focused on was therefore the initial mass concentration of the NP, not their size or agglomeration state immediately after sonication, i.e., just after administration to mice. Finally, although we cannot rule out the technical difficulty of observing and characterizing such aggregates/agglomerates with a regular optical microscope, this result confirms the multifactorial origins potentially linking the presence of NP to any biological effect [36].

Our results overall demonstrate that repeated exposure to NP at doses relevant to occupational exposure represents a potential risk for respiratory health. There is currently no international consensus regarding which OEL can be applied to NP, although they could represent a major component of the occupational pollution [37, 38]; the proposed OEL for NP is $10 \%$ of the exposure limits established for the respective micro-scale industrial aerosols [39]. Indeed, with the exception of nanometric $\mathrm{TiO}_{2}$ for which a recommended exposure limit (REL) at 0.3 
$\mathrm{mg} / \mathrm{m}^{3}$ has been proposed by the US, OEL have been defined for respirable particles only i.e. most of them in the micrometric range [37, 40, 41]. Some NP-specific values have been proposed, but they differ according to the different proposing countries or agencies, in terms of the metric used to quantify the relative exposure to NP or the categorization of NP in various risk groups, background upon which these OEL have been developed [37], which makes these proposed values highly provisional. Moreover, the current OELs don't consider the speciation of NP, although it represents an important determinant of their biological effects.

\section{CONCLUSION}

Overall, our data demonstrate for the first time a potential risk for respiratory health posed by repeated exposure to NP at occupationally-relevant doses. Given these results, the development of OEL specifically dedicated to NP exposure might therefore be an important issue to address in the near future. 


\section{ACKNOWLEDGMENTS}

This work was supported by funds from INSERM, Agence Nationale de la Recherche (grant ANR-09-CESA-017), Université Paris Est-Créteil, Chancellerie des Universités de Paris (Legs POIX), Fonds de Dotation-Recherche en Santé Respiratoire (SPLF), and C'Nano (grant AAP09-NanoSoud). Mirlande Présumé was a fellow from Agence nationale de sécurité sanitaire de l'alimentation, de l'environnement et du travail (ANSES) and Agence de l'Environnement et de la Maîtrise de l'Énergie (ADEME). Angélique Simon-Deckers and Grégory Beaune were both fellows from ANR. Sophie Lanone and Jorge Boczkowski were both recipients of a Contrat de Recherche Translationnelle, between Inserm and CHI Créteil (SL), or CHU Mondor (JB). This work also received the support of Labex SERENADE 11LABX-0064 and DHU A-TVB (Département Hospitalo-Universitaire Ageing-Thorax-VesselBlood).

\section{DECLARATION OF INTEREST}

The authors declare that they have no competing interests. 


\section{REFERENCES}

1. Logan WP: Mortality in the London fog incident, 1952. Lancet 1953, 1:336-338.

2. Atkinson RW, Kang S, Anderson HR, Mills IC, Walton HA: Epidemiological time series studies of PM2.5 and daily mortality and hospital admissions: a systematic review and meta-analysis. Thorax 2014, 69:660-665.

3. Qiu H, Tian LW, Pun VC, Ho KF, Wong TW, Yu IT: Coarse particulate matter associated with increased risk of emergency hospital admissions for pneumonia in Hong Kong. Thorax 2014, 69:1027-1033. 4. Lepeule J, Litonjua AA, Coull B, Koutrakis P, Sparrow D, Vokonas PS, Schwartz J: Long-term effects of traffic particles on lung function decline in the elderly. Am J Respir Crit Care Med 2014, 190:542-548.

5. Delfino RJ, Wu J, Tjoa T, Gullesserian SK, Nickerson B, Gillen DL: Asthma morbidity and ambient air pollution: effect modification by residential traffic-related air pollution. Epidemiology 2014, 25:48-57.

6. Antonini J, Roberts J, Stone S, Chen B, Schwegler-Berry D, Chapman R, Zeidler-Erdely P, Andrews R, Frazer D: Persistence of deposited metals in the lungs after stainless steel and mild steel welding fume inhalation in rats. Archives of Toxicology 2011, 85:487-498.

7. Gomes JF, Albuquerque PC, Miranda RM, Vieira MT: Determination of airborne nanoparticles from welding operations. J Toxicol Environ Health A 2012, 75:747-755.

8. Dasch J, D'Arcy J: Physical and chemical characterization of airborne particles from welding operations in automotive plants. J Occup Environ Hyg 2008, 5:444-454.

9. Stephenson D, Seshadri G, Veranth JM: Workplace exposure to submicron particle mass and number concentrations from manual arc welding of carbon steel. AIHA J (Fairfax, Va) 2003, 64:516-521.

10. Plitzko S: Workplace exposure to engineered nanoparticles. Inhal Toxicol 2009, 21 Suppl 1:25-29.

11. Lee JH, Kwon M, Ji JH, Kang CS, Ahn KH, Han JH, Yu IJ: Exposure assessment of workplaces manufacturing nanosized TiO2 and silver. Inhalation Toxicology 2011, 23:226-236.

12. Xing M, Zhang Y, Zou H, Quan C, Chang B, Tang S, Zhang M: Exposure characteristics of ferric oxide nanoparticles released during activities for manufacturing ferric oxide nanomaterials. Inhalation Toxicology 2015, 27:138-148.

13. Pietroiusti A: Health implications of engineered nanomaterials. Nanoscale 2012, 4:1231-1247.

14. Curwin B, Bertke S: Exposure characterization of metal oxide nanoparticles in the workplace. $J$ Occup Environ Hyg 2011, 8:580-587.

15. Roco MC, Mirkin, Hersam MC: Nanotechnology Research Directions for Societal Needs in 2020. In. Edited by Springer; 2010

16. Antonini JM, Roberts JR, Schwegler-Berry D, Mercer RR: Comparative Microscopic Study of Human and Rat Lungs After Overexposure to Welding Fume. Annals of Occupational Hygiene 2013, 57:1167-1179.

17. Antonini JM, Badding MA, Meighan TG, Keane M, Leonard SS, Roberts JR: Evaluation of the Pulmonary Toxicity of a Fume Generated from a Nickel-, Copper-Based Electrode to be Used as a Substitute in Stainless Steel Welding. Environmental Health Insights 2014:11-20.

18. Andujar P, Simon-Deckers A, Galateau-Salle F, Fayard B, Beaune G, Clin B, Billon-Galland MA, Durupthy O, Pairon JC, Doucet J, et al: Role of metal oxide nanoparticles in histopathological changes observed in the lung of welders. Part Fibre Toxicol 2014, 11:23.

19. ICRP: Canada: ICRP Publication 66; 1994.

20. NIOSH: Appendix G: 1989 Air contaminants update project - exposure limits NOT in effect. http://www.cdc.gov/niosh/npg/nengapdxg.html. 2015.

21. Paek D, McCool FD: Breathing patterns during varied activities. J Appl Physiol (1985) 1992, 73:887-893.

22. Présumé M, Attoui M, Maisser A, Petit G, Lanone S: Design and Characterization of an Inhalation System of Iron and Manganese Oxide Nanoparticles for Rodent Exposure. Aerosol Science and Technology 2015, 49:580-588.

23. Ashcroft T, Simpson JM, Timbrell V: Simple method of estimating severity of pulmonary fibrosis on a numerical scale. J Clin Pathol 1988, 41:467-470.

24. Boczkowski J, Lanone S: Respiratory toxicities of nanomaterials - A focus on carbon nanotubes. Adv Drug Deliv Rev 2012, 64:1694-1699.

25. Sarkar A, Ghosh M, Sil PC: Nanotoxicity: oxidative stress mediated toxicity of metal and metal oxide nanoparticles. J Nanosci Nanotechnol 2014, 14:730-743.

26. Park EJ, Kim H, Kim Y, Yi J, Choi K, Park K: Inflammatory responses may be induced by a single intratracheal instillation of iron nanoparticles in mice. Toxicology 2010, 275:65-71.

27. Oberdörster G, Yu CP: Lung dosimetry - Considerations for noninhalation studies. Exp Lung Res 1999, 25:1-6. 
28. Szalay B, Tatrai E, Nyiro G, Vezer T, Dura G: Potential toxic effects of iron oxide nanoparticles in in vivo and in vitro experiments. $J$ Appl Toxicol 2012, 32:446-453.

29. Zhu MT, Feng WY, Wang B, Wang TC, Gu YQ, Wang M, Wang Y, Ouyang H, Zhao YL, Chai ZF: Comparative study of pulmonary responses to nano- and submicron-sized ferric oxide in rats. Toxicology 2008, 247:102-111.

30. Totsuka Y, Ishino K, Kato T, Goto S, Tada Y, Nakae D, Watanabe M, Wakabayashi K: Magnetite Nanoparticles Induce Genotoxicity in the Lungs of Mice via Inflammatory Response. Nanomaterials 2014, 4:175.

31. Gustafsson A, Bergstrom U, Agren L, Osterlund L, Sandstrom T, Bucht A: Differential cellular responses in healthy mice and in mice with established airway inflammation when exposed to hematite nanoparticles. Toxicol Appl Pharmacol 2015, 288:1-11.

32. Cho W-S, Cho M, Kim SR, Choi M, Lee JY, Han BS, Park SN, Yu MK, Jon S, Jeong J: Pulmonary toxicity and kinetic study of Cy5.5-conjugated superparamagnetic iron oxide nanoparticles by optical imaging. Toxicology and Applied Pharmacology 2009, 239:106-115.

33. Zhang H, Ji Z, Xia T, Meng H, Low-Kam C, Liu R, Pokhrel S, Lin S, Wang X, Liao YP, et al: Use of metal oxide nanoparticle band gap to develop a predictive paradigm for oxidative stress and acute pulmonary inflammation. ACS Nano 2012, 6:4349-4368.

34. Antonini JM: Health effects of welding. Crit Rev Toxicol 2003, 33:61-103.

35. Liu X, Fang S, Liu H, Wang X, Dai X, Yin Q, Yun T, Wang W, Zhang Y, Liao H, et al: Role of human pulmonary fibroblast-derived MCP-1 in cell activation and migration in experimental silicosis. Toxicology and Applied Pharmacology 2015, 288:152-160.

36. Lanone S, Andujar P, Kermanizadeh A, Boczkowski J: Determinants of carbon nanotube toxicity. Adv Drug Deliv Rev 2013.

37. Pietroiusti A, Magrini A: Engineered nanoparticles at the workplace: current knowledge about workers' risk. Occup Med (Lond) 2014, 64:319-330.

38. O'Shaughnessy PT: Occupational health risk to nanoparticulate exposure. Environmental science Processes \& impacts 2013, 15:49-62.

39. Katsnelson BA, Privalova LI, Sutunkova MP, Gurvich VB, Loginova NV, Minigalieva IA, Kireyeva EP, Shur VY, Shishkina EV, Beikin YB, et al: Some inferences from in vivo experiments with metal and metal oxide nanoparticles: the pulmonary phagocytosis response, subchronic systemic toxicity and genotoxicity, regulatory proposals, searching for bioprotectors (a self-overview). Int J Nanomedicine 2015, 10:3013-3029.

40. NIOSH: Current intelligence bulletin 63. Occupational exposure to titanium dioxide. http://www.cdc.gov/niosh/docs/2011-160/pdfs/2011-160.pdf. 2011.

41. van Broekhuizen P, Dorbeck-Jung B: Exposure limit values for nanomaterials--capacity and willingness of users to apply a precautionary approach. J Occup Environ Hyg 2013, 10:46-53. 


\section{LEGEND TO FIGURES}

Figure 1: Histological analysis of lung tissue sections after repeated exposure to $5 \mu \mathrm{g}$ NP. Representative optical microscopy images of lung tissue sections from a control mouse and mice weekly exposed during 3 months to $5 \mu \mathrm{g} \mathrm{Fe}_{2} \mathrm{O}_{3}, \mathrm{Fe}_{3} \mathrm{O}_{4}, \mathrm{MnFe}_{2} \mathrm{O}_{4}$ or $\mathrm{CrOOH} \mathrm{NP}$. Sections were stained with hematoxylin-eosin-saffron (HES) (Panel A) or Sirius Red (Panel B). Scale bar: $100 \mu \mathrm{m}$. Quantification of histological alterations in terms of alveolar, peribronchiolar, perivascular wall thickness or interstitial lung inflammation (Panel C). *: $\mathrm{p} \leq 0.05$ vs Control. **: $\mathrm{p} \leq 0.01$ vs Control.

Figure 2: Histological analysis of lung tissue sections after repeated exposure to $50 \mu \mathrm{g}$ NP. Representative optical microscopy images of lung tissue sections from a control mouse and mice weekly exposed during 3 months to $50 \mu \mathrm{g} \mathrm{Fe}_{2} \mathrm{O}_{3}, \mathrm{Fe}_{3} \mathrm{O}_{4}, \mathrm{MnFe}_{2} \mathrm{O}_{4}$ or $\mathrm{CrOOH} \mathrm{NP}$. Sections were stained with hematoxylin-eosin-saffron (HES) (Panel A) or Sirius Red (Panel B). Scale bar: $100 \mu \mathrm{m}$. Quantification of histological alterations in terms of alveolar, peribronchiolar, perivascular wall thickness or interstitial lung inflammation (Panel C). *: $\mathrm{p} \leq 0.05$ vs Control. $* *: \mathrm{p} \leq 0.01$ vs Control. $* * *: \mathrm{p} \leq 0.001$ vs Control.

Figure 3: Analysis of agglomerates/aggregates accumulation in lung tissue sections. Representative optical microscopy images of lung tissue sections from a control mouse and mice weekly exposed during 3 months to $50 \mu \mathrm{g} \mathrm{Fe}_{2} \mathrm{O}_{3}, \mathrm{Fe}_{3} \mathrm{O}_{4}, \mathrm{MnFe}_{2} \mathrm{O}_{4}$ or $\mathrm{CrOOH}$ NP (Panel A). Sections were stained with HES. Scale bar: $30 \mu \mathrm{m}$. Quantification of agglomerates accumulation (Panel B). Data are given as mean number of agglomerates/aggregates per field observed in at least 10 fields per animal. *: $\mathrm{p} \leq 0.05$ vs Control. **: $\mathrm{p} \leq 0.01$ vs Control. ***: $\mathrm{p} \leq 0.001$ vs Control. 
Figure 4: BALF analysis of mice exposed to NP for 1 month. BALF total protein content, LDH release and total cellularity of mice weekly exposed for 1 month to $5 \mu \mathrm{g}$ (Panel A) or 50 $\mu \mathrm{g}$ (Panel B) NP. BALF levels of TNFa, TGF $\beta$ and IL1 $\beta$ in mice weekly exposed for 1 month to $5 \mu \mathrm{g}$ (Panel C) or $50 \mu \mathrm{g}$ (Panel D) NP. n: 8 mice per condition. *: $\mathrm{p} \leq 0.05$ vs Control. **: $\mathrm{p} \leq 0.01$ vs Control.

Figure 5: BALF analysis of mice exposed to NP for 3 months. BALF total protein content, LDH release and total cellularity of mice weekly exposed for 3 months to $5 \mu \mathrm{g}$ (Panel A) or $50 \mu \mathrm{g}$ (Panel B) NP. BALF levels of TNFa, TGF $\beta$ and IL1 $\beta$ in mice weekly exposed for 3 months to $5 \mu \mathrm{g}$ (Panel C) or $50 \mu \mathrm{g}$ (Panel D) NP. n: 8 mice per condition. *: $\mathrm{p} \leq 0.05$ vs Control. **: $\mathrm{p} \leq 0.01$ vs Control.

Figure 6: Total lung mRNA analysis of mice exposed to NP for 1 month. Quantification of TNFa, MCP-1, IL-6, PTGS, RANTES, NQO-1 and CYP1A1 mRNA expression in lung sample from mice weekly exposed for 1 month to $5 \mu \mathrm{g}$ (Panel A) or $50 \mu \mathrm{g}$ (Panel B) NP. n: 8 mice per condition. Data are given as the ration between mRNA of interest's expression to that of GAPDH, and normalized to the Control condition. *: $\mathrm{p} \leq 0.05$ vs Control. **: $\mathrm{p} \leq 0.01$ vs Control. ***: $\mathrm{p} \leq 0.001$ vs Control.

Figure 7: Total lung mRNA analysis of mice exposed to NP for 3 months. Quantification of TNFa, MCP-1, IL-6, PTGS, RANTES, NQO-1 and CYP1A1 mRNA expression in lung sample from mice weekly exposed for 3 months to $5 \mu \mathrm{g}$ (Panel A) or $50 \mu \mathrm{g}$ (Panel B) NP. n: 8 mice per condition. Data are given as the ration between mRNA of interest's expression to 
that of GAPDH, and normalized to the Control condition. *: $\mathrm{p} \leq 0.05$ vs Control. **: $\mathrm{p} \leq 0.01$ vs Control. ***: $\mathrm{p} \leq 0.001$ vs Control.

Figure 8: Heme-Oxygenase-1 (HO-1) expression in lung tissue sections. Representative optical microscopy images of lung tissue sections stained for HO-1 protein from a control mouse and mice weekly exposed during 3 months to $50 \mu \mathrm{g} \mathrm{Fe}_{2} \mathrm{O}_{3}, \mathrm{Fe}_{3} \mathrm{O}_{4}, \mathrm{MnFe}_{2} \mathrm{O}_{4}$ or CrOOH NP. Scale bar: $100 \mu \mathrm{m}$.

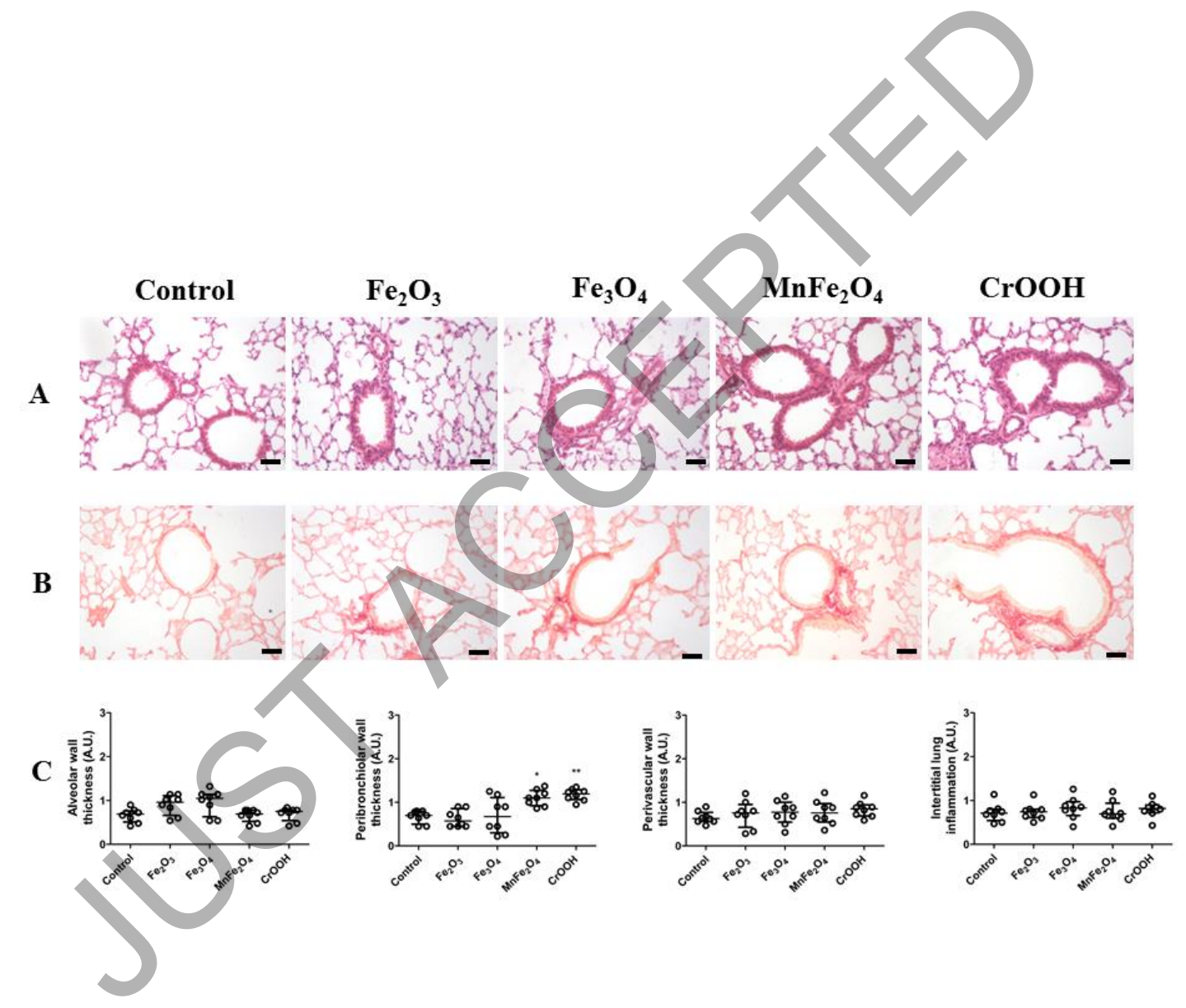




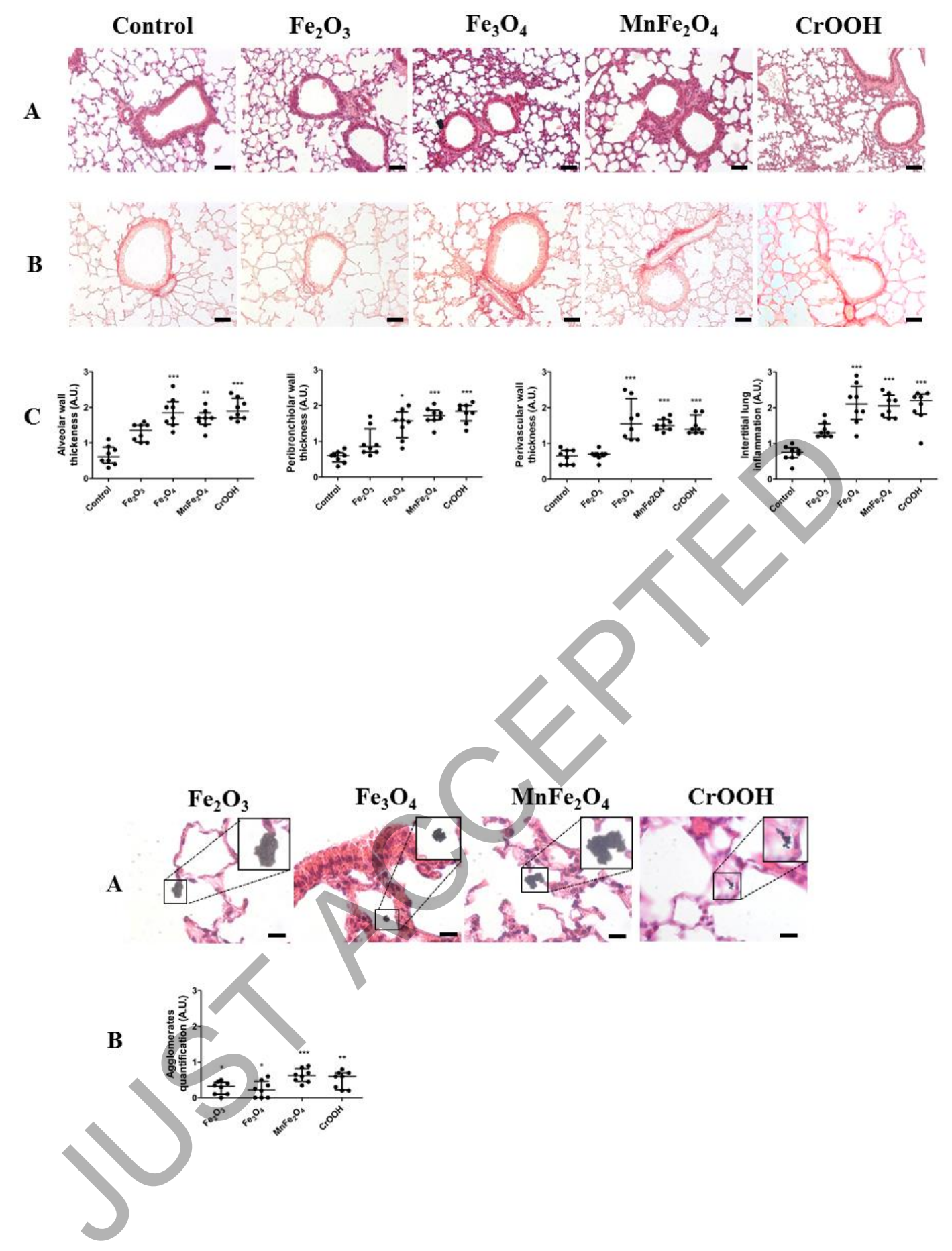




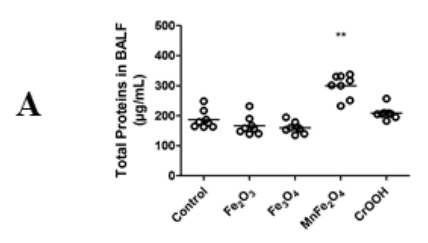

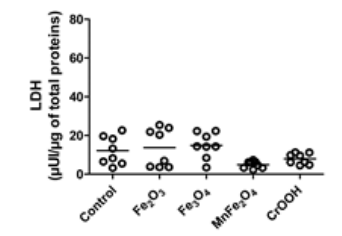

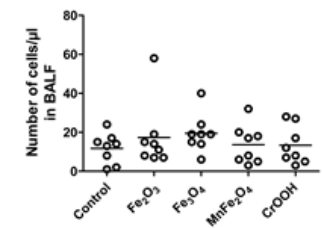

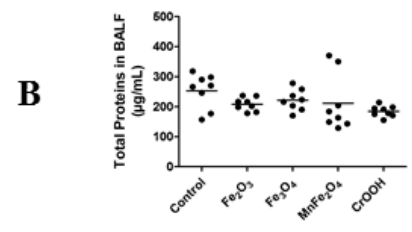

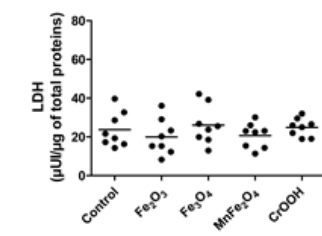

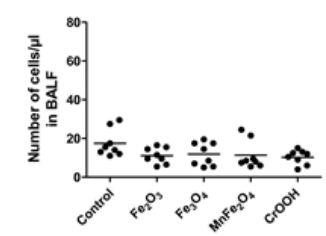
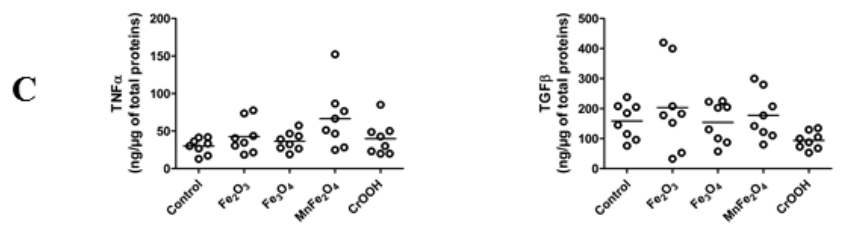

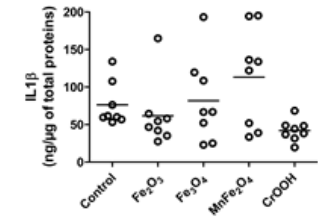
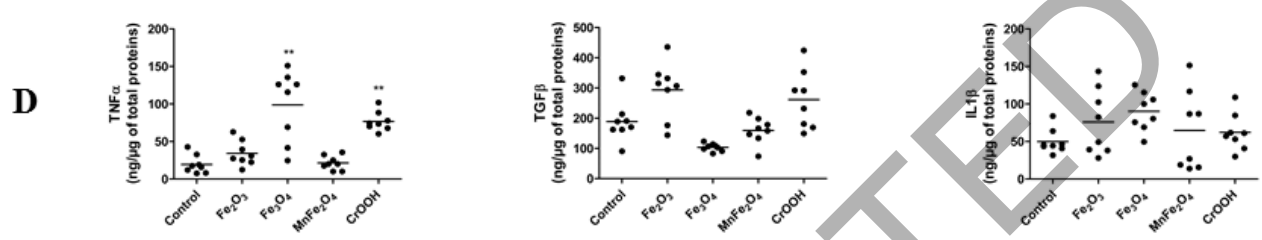

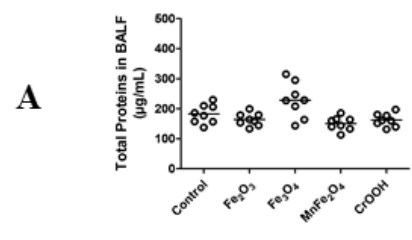
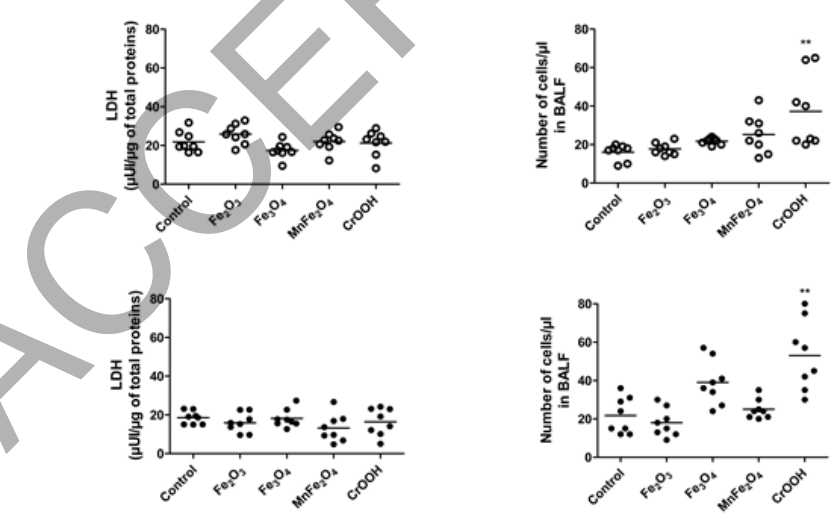

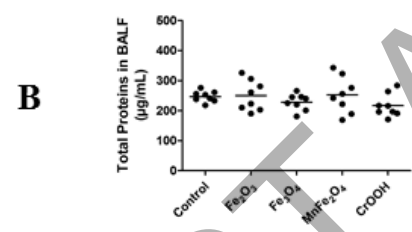

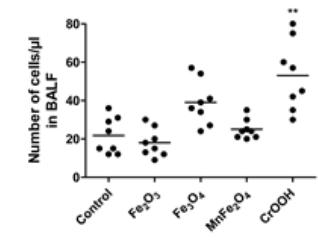
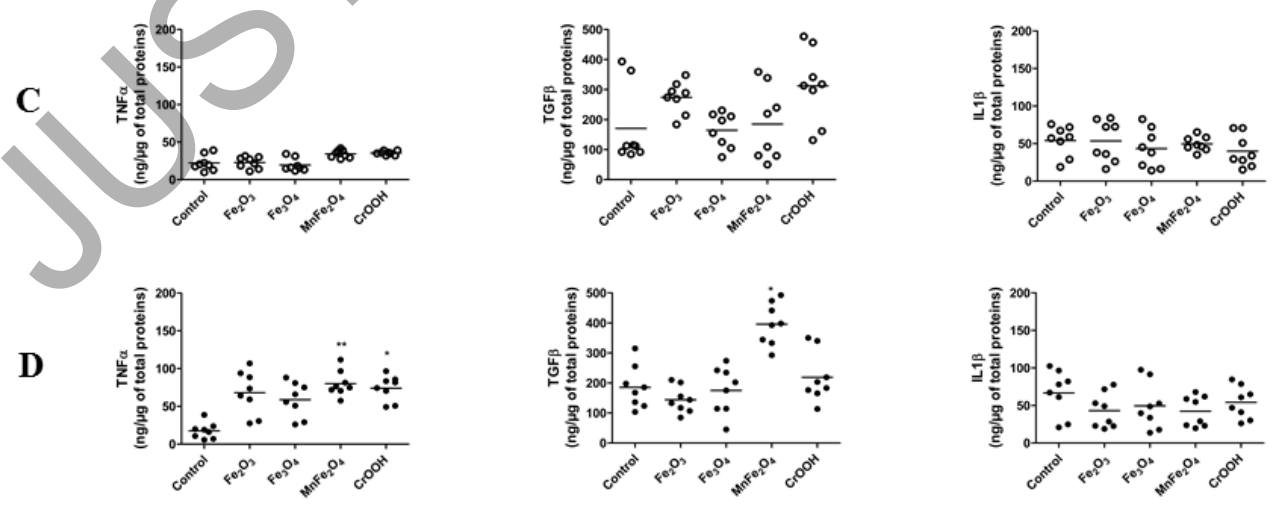

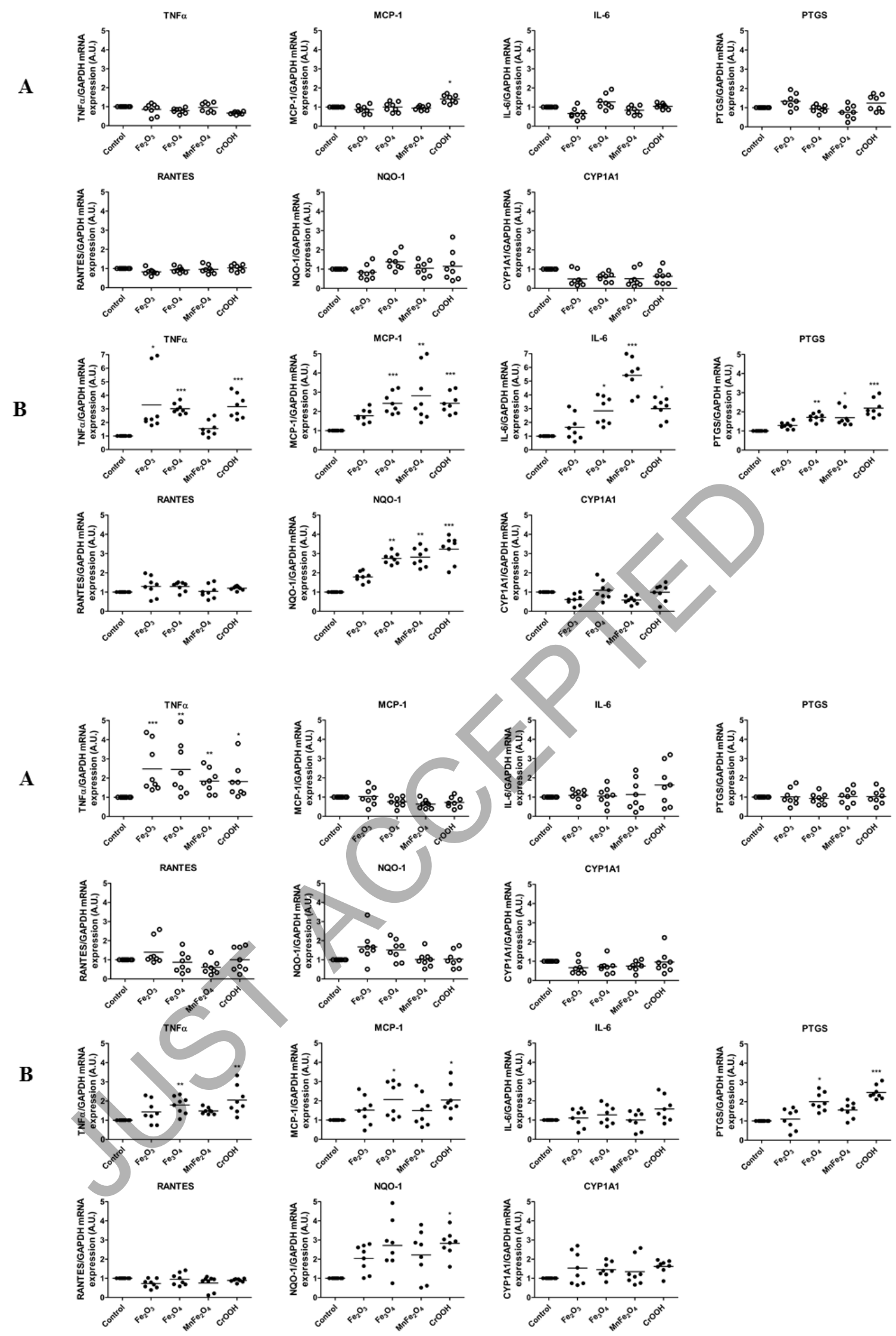


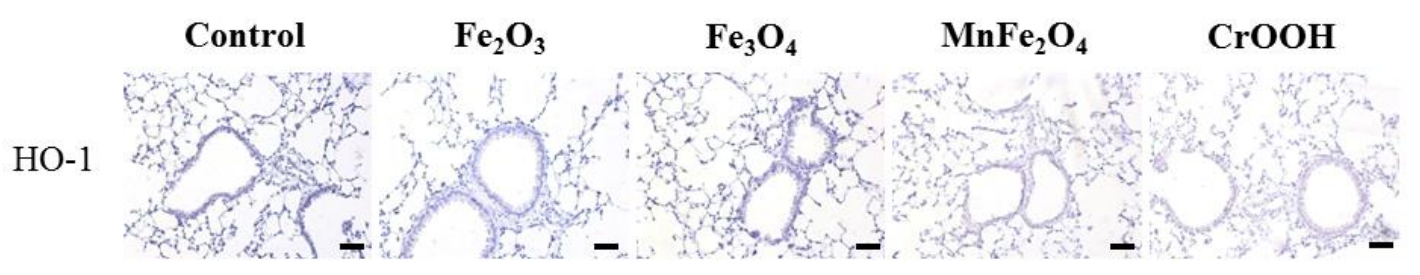

